\title{
BIOCHEMICAL STUDIES ON THE EFFECT OF ONION ON SOME BLOOD PARAMETERS OF RATS
}

\author{
M. A Habib, Kh. M. Taha and A. F. A. Sheta \\ Agricultural Biochemistry Department, Faculty of Agriculture, Menoufia University \\ Received: Oct. 10, 2021 \\ Accepted: Nov. 18, 2021
}

\begin{abstract}
The objective of the present research was to study chemical composition, phenolic compounds and flavonoids of onion. Onion contained total carbohydrates $70.7 \%$, crude protein $7.35 \%$, total lipids $1.43 \%$, total ash $2.91 \%$ fibers $7.91 \%$ and moisture $9.7 \%$ based the dry sample. Total phenols in onion bulbs was $35.23 \mathrm{mg} / 100 \mathrm{~g}$., while the total flavonoids was $23.18 \mathrm{mg} / 100 \mathrm{~g}$. HPLC results showed that onion contained 17 phenolic compounds. There were a high percentage of (benzoic acid $905 \mathrm{mg} / \mathrm{kg}$ ), caticol $(649 \mathrm{mg} / \mathrm{kg})$, risvertol $(425 \mathrm{mg} / \mathrm{kg})$, perogalol $(157 \mathrm{mg} / \mathrm{kg})$ and naringinin $(96$ $\mathrm{mg} / \mathrm{kg}$ ). that help to improve some blood parameters such as liver function enzymes, kidneys function, lipids and glucose levels. Onion powder as well as ethanolic and water extracts of onion bulbs were prepared which used in the present treatments. Blood parameters of rats were tested using the methods of A.O.A.C.; (2005). Onion powder used as a treatment with concentration of $2 \mathrm{~g} \%$ and $4 \mathrm{~g} \%$ of diet. The ethanolic extract of onion used as a treatment with concentration of $1 \mathrm{~g} / \mathrm{L}$ and $2 \mathrm{~g} / \mathrm{L}$. While water extract used as a treatment with concentration of $1 \mathrm{~g} / \mathrm{L}$ and $2 \mathrm{~g} / \mathrm{L}$ for hyperlipidemic rats. Blood parameters of rats were tested after the treatments. Data were subjected to statistical analysis using the SPSS (Software version no. 20). Differences between extracts were tested. The best results were obtained by comparisons of the results shown.
\end{abstract}

Treatments with onion powder and its extracts were beneficial to control the hyperlipidemia, and improved the levels of some blood parameters of rats such as, total cholesterol, HDL-c, LDL-c, TG, ALT, AST, creatinine, urea, uric acid, blood glucose.

Key words: Onion, HPLC, Phenolic compound, Flavonoids, blood parameters, Hyperlipidemia, rats.

\section{INTRODUCTION}

Since the dawn of history, plants have been a source of foods, diseases treatments and prevention. Some plants are known as a medicinal plants. They are known to be the big source of many medicines in modern times. Onion (Allium cepa), was one of these plants, it is not only used as a food or additives for specific taste and flavor to food but also contribute for good health. Onion is rich in bioactive components that offer numerous health benefits, it also contain phenols, flavonoids, fibers, and they have antioxidant roles in life bodied. There are several reports showing that the onion has medicinal properties as, anti- bacterial, (Skerget et al; 2009), antivairal, anticancerous and antiinflammatory effect, (Atkin et al; 2016), anticoagulant effect and reducing cardiovascular; (Tejani, 2013), antidiabetic, antihypertensive and hypolipidemic properties; (Sainani et al; 1979 and Ashraf et al; 2005). On the other hand, many epidemiological studies confirmed the connection between the consumption of onion vegetables and decrease the risk for development of many diseases, (Upadhyay, 2016). Onion has a long history of folk medicine. Modern science has recognized the beneficial medical effects of this plant, which has widespread uses in improving 
some blood parameters those subjected the present study. Research has shown that the components of these plants have the ability to prevent the emergence of hyperlipidemia and some blood components and helps to reduce the side effects of chemical treatments. Blood fats produced by the liver, and it consists of triglycerides, total cholesterol, HDL-c high density lipoprotein, LDL-c low density lipoprotein and vLDL-c very low density lipoprotein ...etc, (Kendrick et al; 1998). Sometimes it happens to be less than or more than normal levels in blood. Hyperlipidemia means increasing of fat levels in the bloo. In many cases it was the major reason of, diabetes, blood clots, obesity, hyperlipidemia, hypertension, and cardiovascular,...etc.), (Wouters et al; 2005). The present study aims to clarify the effect of onion and its extracts with different concentrations on the high levels of some blood components in experimental rats. The hypolipidemic effects of onion were investigated through food intake with program of high fat diet HFD making a hyperlipidemia in rats which caused in increasing levels of some blood components, then using onion powder in two concentrations $2 \mathrm{~g} \%$ and $4 \mathrm{~g} \%$. And also using $\mathrm{H}_{2} \mathrm{O}$ extracts and ethanolic extracts in two concentration $1 \mathrm{~g} / \mathrm{L}$ and 2 $\mathrm{g} / \mathrm{L}$ as treatments through experimentation. Determination the effect of onion on blood parameters in the experimental animals (mal albino rats) through comparisons between the results of blood analysis in different groups and the controls, by statistical analysis to highlight the effect of onion and its extracts on blood chemical analysis reaching to the best treatment of onion in blood parameters.

\section{MATERIALS AND METHODS}

\section{Samples collection:}

Fresh onion (Allium cepa L.) bulbs was purchased from local market; identified by horticultural department, Faculty of Agriculture, Menoufia University. Plant sample was washed and air-dried for 24 hours, then dried at $40 \circ \mathrm{C}$. The dried sample was grinded into fine powder to pass $100 \mathrm{~mm}$ filter and kept in a sterile container.

\section{Methods:}

\section{Preparation of plant extracts:}

The Frist $200 \mathrm{~g}$ of the dried plant powder was dissolved in one liter ethanol 95\%. The second: $200 \mathrm{~g}$ powdered sample was extracted with one liter of $\mathrm{H}_{2} \mathrm{O}$. with stirring for 48 hours then, filtered through double layers of muslin, centrifuged at $9000 \mathrm{xg}$ for $10 \mathrm{~min}$ and finally filtered again through Whatman filter paper number 41 to attain a clear filtrate. The filtrates were evaporated and dried at $40^{\circ} \mathrm{C}$ under reduced pressure using rotatory vacuum evaporator. Finally, the extract was collected and stored in refrigerator at $4^{\circ} \mathrm{C}$ (Gauthami et al; 2015).

\section{Major chemical composition:}

After bringing the samples to uniform size, they were analyzed for ash, moisture, fiber, protein and fat which determined according to A.O.A.C., (2005) and carbohydrates were by Dubois et al; (1956). All conducted in the Graduate Laboratory, Department of Biochemistry, Faculty of Agriculture, Menoufia University.

\section{Determination of total phenolic compounds in different extracts:}

The amounts of total phenols in the studies extracts were determined spectrometrically with the Folin-Ciocalteu reagent. Gallic acid was used as a standard and the total phenols were expressed as $\mathrm{mg}$ gallic acid equivalents (GAE)/g dry weigh. (Kim et al; 2013). 
Determination of total flavonoids amounts in different extracts:

The total flavonoids contents were determined using the method reported by Dewanto et al; (2002). The results were expressed as $\mathrm{mg}$ of catechin equivalents (CE)/g dry weight.

\section{Quantitative fractionation analysis} of phenolic compounds by HPLC:

Phenolic compounds were analyzed, fractionated, and determined at the Department of Food Science, Faculty of Agriculture, Cairo University according to the method of (Goupy et al; 1999), by using HPLC Hewilet pckared (series 1050) equipped with auto-sampler injection, solvent degasser, Ultra violet (UV) detector set at $280 \mathrm{~nm}$. and quaternary HP pump (series 1050). Hewlett Packard using a column Alltima C18, $5 \mathrm{~mm}$ (150 $\mathrm{mm} \times 4.6 \mathrm{~mm}$ Allech). The column temperature was maintained at $35^{\circ} \mathrm{c}$. Gradient separation was carried out with methanol and acetonitrile as a mobile phase at flow rate of $1 \mathrm{ml} / \mathrm{min}$. Standards were dissolved in a mobile phase and injected into HPLC. Retention time and peak area were used to calculate phenolic compounds concentration by the data of Hewllet packared software.

\section{Experimental animal design:}

Male albino rats were used in the present experiment, all rats were fed normal diet for one week after arrival 'for adaptation. For induction of hyperlipidemia, all groups (except the normal control group) were fed on high fat diet (HFD). Sheep tail fat was used on the way to induce hyperlipidemia. They were then randomly assigned into 8 groups (5 rats per group) as follow, Treatment is taken by the gastric tube and the dose is one $\mathrm{ml}$ for rat perday. Treatment is taken from day 30 (zero time) till the end of the experiment (day 60).

\section{Blood sampling:}

Blood samples were collected after 12 - 14 hours fasting in days: 30 zero time after hyperlipidemia, 45 during of treatment and 60 at the end of experiment in dry, clean tubes without any anticoagulant from the eye plexuses of experimental rats under diethyl ether anesthesia and let samples in an incubator for $20 \mathrm{~min}$., then centrifuged at $3500 \mathrm{xg}$ for 10 minute to collect sera. At the end of the experiment after 60day, rats were killed by decapitation.

Blood samples were analyzed for parameters, total cholesterol, HDL, LDL, TG, ALT, AST, creatinine, urea, uric acid and blood glucose by using methods of A.O.A.C.; (2005), and results were calculated.

\section{Statistical analysis:}

The data were subjected to statistical analysis using the SPSS (Software version no. 20). Differences between extracts were tested by one-way analysis of variance (ANOVA). Probability value for the statistical test was $0.5 \%$.

\section{RESULTS AND DISCUSSIONS}

\section{Major chemical composition of onion.}

Composition has been analyzed three times, and the average results have been displayed.

The results displayed in Table (1) show the $\%$ of the major chemical components of onion on a dry matter base. The results show that the onion contain moisture $9.7 \%$, total carbohydrate $70.7 \%$, total protein $7.35 \%$, lipids $1.43 \%$, fibers $7.91 \%$ and ash $2.91 \%$.

Determination of phenolic and flavonoide compounds in onion bulbs:

Composition has been analyzed three times, and the average results have been displayed. 
M. A Habib, et al.,

Table (1): Experimental groups with diet and treatment design.

\begin{tabular}{cll}
\hline Gr. No. & \multicolumn{1}{c}{ Diet } & \multicolumn{1}{c}{ Treatment } \\
\hline 1 & Standard diet & No treatment. \\
\hline 2 & HFD & No treatment. \\
3 & HFD + treatment & Onion powder $2 \%$ of diet. \\
4 & HFD + treatment & Onion powder $4 \%$ of diet. \\
5 & HFD + treatment & One $\mathrm{ml}$ ingested into a rat of onion ethanolic extract $1 \mathrm{~g} / \mathrm{L}$. \\
6 & HFD + treatment & One $\mathrm{ml}$ ingested into a rat of onion ethanolic extract $2 \mathrm{~g} / \mathrm{L}$. \\
7 & HFD + treatment & One $\mathrm{ml}$ ingested into a rat of onion water extract $1 \mathrm{~g} / \mathrm{L}$. \\
8 & HFD + treatment & One $\mathrm{ml}$ ingested into a rat of onion water extract $2 \mathrm{~g} / \mathrm{L}$. \\
\hline
\end{tabular}

The results displayed in Table (2) show the \% of the major chemical components of onion on a dry matter base. The results show that the onion contain moisture 9.7\%, total carbohydrate $\mathbf{7 0 . 7} \%$, total protein $7.35 \%$, lipids $1.43 \%$, fibers $7.91 \%$ and ash $2.91 \%$.

The results in Table (3) show that the onion contain total phenols $35.23 \mathrm{mg} / \mathrm{g}$ dm. total flavonoids $23.81 \mathrm{mg} / \mathrm{g} \mathrm{dm}$. These results are in line with the results published by Duan et al; (2015).

\section{Fractionation and identification of phenolic components in onion:}

Data in Table (4) shows that the major phenolic compounds in onion.

More than 100 ppm.: Benzoic acid 905.0 ppm, Catechol 649.6, Resvertol 425.9, Pyrogallol 157.0 and Naringenin 96.6 .

Also data in Table (4) show that the minor phenolic compounds in onion (6.0 - 90 ppm.): Quercitin 18.0 ppm, Quinol $14.0 \mathrm{ppm}$, Caffiec acid $9.5 \mathrm{ppm}$, Kaempferol $5.7 \mathrm{ppm}$ and Cholorogenic $5.6 \mathrm{ppm}$.

\section{Effect of onion and its extracts on blood components of rats:}

The results in Table (5) shows the effect of onion treatments on rats fed on a high fat diet. It is clear from the search results a significant increase in cholesterol, HDL-c, LDL-c, TG, levels; while all groups treated with onion showed highly significant decrease in the same parameter levels compared with positive control group.

Results also indicate that onion ethanolic extract treatment $2 \mathrm{~g} / \mathrm{L}$ is the best among all treatments followed by onion ethanolic extract treatment $1 \mathrm{~g} /$ and both of them showed a significant decrease close to the normal control group.

These results are in line with the results published by, Kim et al; (2013).

\section{Effect of onion and its extracts on kidney functions and blood glucose in rats:}

The results in Table (6) show the effect of onion treatments on the kidneys functions and blood glucose rats fed on a high fat diet. It is clear from the search results a significant increase in urea, creatinine, uric acid and blood glucose levels, while all groups treated with onion showed highly significant decrease in the same parameter levels compared with positive control group.

Results also indicate that onion ethanolic extract treatment $2 \mathrm{~g} / \mathrm{L}$ is the best among all treatments followed by onion ethanolic extract treatment $1 \mathrm{~g} / \mathrm{L}$ and both of them showed a significant decrease close to the normal control group. 
These results are in line with the results published by, Jelodar et al; (2005), Haidari et al; (2008) and Kumar et al; (2011).

Effect of onion and its extracts on liver functions (AST \& ALT) in Rats:

The results in Table (7) show the effect of onion treatments on rats fed on a high fat diet. It is clear from the search results that there are a significant increases in ALT and AST activity levels of hyperlipidemic rats while all groups treated with onion showed highly significant improvement in the same parameter levels compared with positive control group.

Table (2): The major chemical composition of onion dry matter \% .

\begin{tabular}{ccccccc}
\hline Component: & Moisture & Carbohydrate & Protein & Lipids & Ash & Fibers \\
& 9.7 & 70.7 & 7.35 & 1.43 & 2.91 & 7,91 \\
$\%$ & \pm 0.4 & \pm 2.3 & \pm 0.3 & \pm 0.1 & \pm 0.1 & \pm 0.3 \\
\hline
\end{tabular}

Table (3): Total phenolic and total flavonoide compounds in onion bulbs.

\begin{tabular}{|c|c|c|c|c|}
\hline \multicolumn{5}{|c|}{ Component in the onion dry matter } \\
\hline \multirow{2}{*}{\multicolumn{3}{|c|}{$\begin{array}{l}\text { Total phenols content (TPC) } \\
\text { Total flavonoids content (TFC) }\end{array}$}} & $35.23 \pm 1.4$ & $\mathrm{mg} / \mathrm{g}$ dry weight \\
\hline & & & $23.81 \pm 1.3$ & $\mathrm{mg} / \mathrm{g}$ dry weight \\
\hline No. of & fractions & \multicolumn{2}{|c|}{ Phenolic compounds } & Onion Conc. ppm \\
\hline & 1 & \multicolumn{2}{|c|}{ Pyrogallol } & 157 \\
\hline & 2 & \multicolumn{2}{|c|}{ Quinol } & 14 \\
\hline & 3 & \multicolumn{2}{|c|}{ Gallic acid } & 1.6 \\
\hline & 4 & \multicolumn{2}{|c|}{ Catechol } & 650.0 \\
\hline & 5 & \multicolumn{2}{|c|}{ P-Hydroxy benzoic acid } & 5.0 \\
\hline & 6 & \multicolumn{2}{|c|}{ Catechin } & 4.1 \\
\hline & 7 & \multicolumn{2}{|c|}{ Cholorogenic } & 5.6 \\
\hline & 8 & \multicolumn{2}{|c|}{ Vanillic acid } & 4.1 \\
\hline & 9 & \multicolumn{2}{|c|}{ Caffiec acid } & 9.5 \\
\hline & 10 & \multicolumn{2}{|c|}{ Benzoic acid } & 905 \\
\hline & 11 & \multicolumn{2}{|c|}{ Ferullic acid } & 3.6 \\
\hline & 12 & \multicolumn{2}{|c|}{ Ellagic } & Not detected \\
\hline & 13 & \multicolumn{2}{|c|}{ O-Coummaric acid } & 3.3 \\
\hline & 14 & \multicolumn{2}{|c|}{ Resvertol } & 426.0 \\
\hline & 15 & \multicolumn{2}{|c|}{ Cinnamic acid } & 2.1 \\
\hline & 16 & \multicolumn{2}{|c|}{ Quercitin } & 18.0 \\
\hline & 17 & \multicolumn{2}{|c|}{ Naringenin } & 96.6 \\
\hline & 18 & \multicolumn{2}{|c|}{ Myricetin } & Not detected \\
\hline & 19 & \multicolumn{2}{|c|}{ Kaempferol } & 5.7 \\
\hline \multicolumn{2}{|c|}{ Total amount } & & & $2310.7 \mathrm{ppm}$ \\
\hline
\end{tabular}




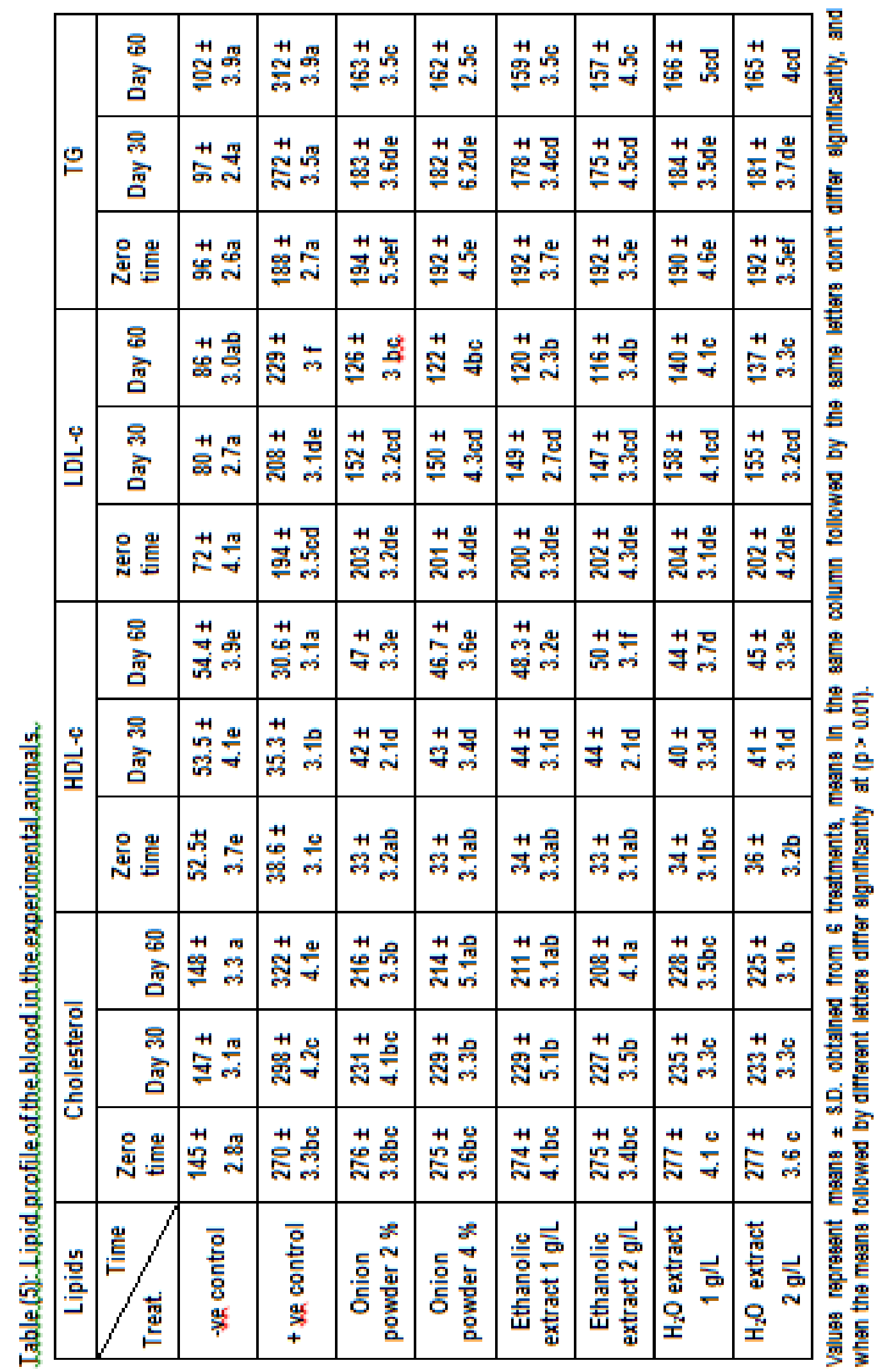




\begin{tabular}{|c|c|c|c|c|c|c|c|c|c|}
\hline \multirow{3}{*}{ 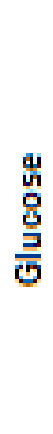 } & $\begin{array}{l}\text { 昌 } \\
\text { 夏 }\end{array}$ & 苞 & 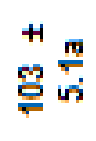 & 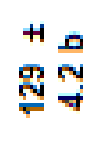 & 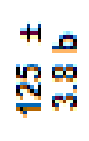 & مَ & 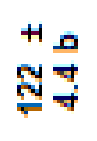 & $\begin{array}{l}\text { مـ } \\
\text { 감 }\end{array}$ & 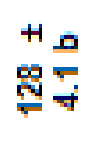 \\
\hline & 鬲 & $\begin{array}{l}\text { Hั } \\
\text { శ్ }\end{array}$ & 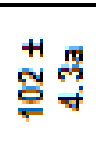 & 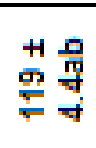 & 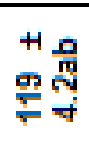 & $\stackrel{+}{H} \stackrel{+0}{=}$ & 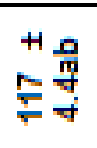 & 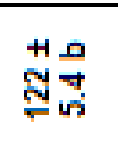 & 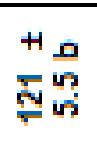 \\
\hline & 这 & 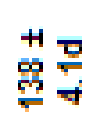 & $\begin{array}{l}\text { H } \\
\text { ng } \\
\text { 워 }\end{array}$ & 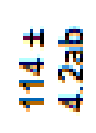 & $\stackrel{+1}{+0}$ & 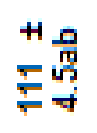 & $\begin{array}{l}\text { H量 } \\
\text { 읕 }\end{array}$ & 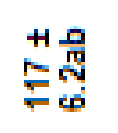 & 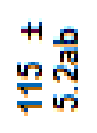 \\
\hline \multirow{3}{*}{$\begin{array}{l}\text { 믈 } \\
\text { गٕ } \\
\text { 은 }\end{array}$} & $\begin{array}{l}\text { 品 } \\
\text { 吾 }\end{array}$ & 莳 & 警哭 & 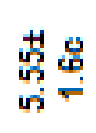 & 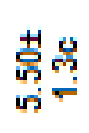 & $\begin{array}{l}+1 \\
\text { ñ } \\
\text { ni }\end{array}$ & 䓵 & 葛 & 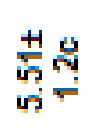 \\
\hline & 을 & 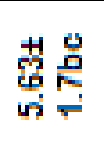 & 莺䀡 & 芒 & 嵌 & 䓠虽 & 초ำ & 草 & 擎导 \\
\hline & 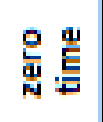 & 苦导 & 莴管 & 贲思 & 芒罢 & 晜思 & 芯 & 萦昜 & 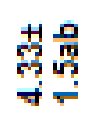 \\
\hline \multirow{3}{*}{ 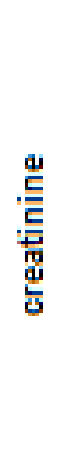 } & $\begin{array}{l}\stackrel{0}{6} \\
\text { 夏 }\end{array}$ & 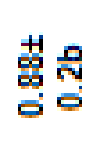 & 苟 & 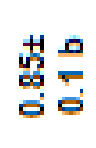 & $\begin{array}{l}\text { 苦令 } \\
\text { c。 }\end{array}$ & 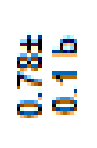 & 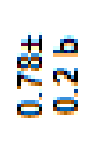 & 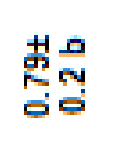 & 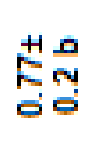 \\
\hline & 窝 & 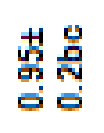 & $\begin{array}{l}\text { 苟 } \\
\text { 思 }\end{array}$ & 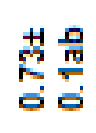 & 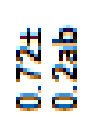 & 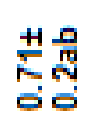 & 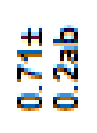 & $\begin{array}{l}\text { 茠量 } \\
\text { 。 }\end{array}$ & 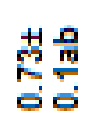 \\
\hline & 원 른 & 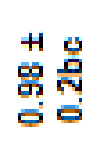 & 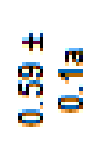 & 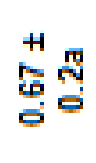 & 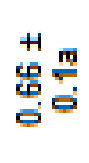 & 苞 & ஜ & $\begin{array}{l}+1 \\
\text { 명 } \\
\text { 영 }\end{array}$ & 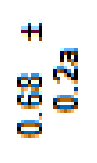 \\
\hline \multirow{3}{*}{ 䍡 } & $\begin{array}{l}\stackrel{0}{6} \\
\text { 吾 }\end{array}$ & 草尊 & 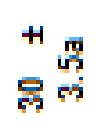 & 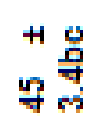 & H & $\begin{array}{l}\text { H } \\
\text { में }\end{array}$ & $\begin{array}{l}+ \\
\text { H } \\
\text { n }\end{array}$ & $\begin{array}{l}\text { He } \\
\text { चे }\end{array}$ & के \\
\hline & 常 & 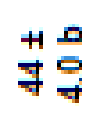 & 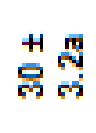 & $\begin{array}{l}+ \\
\text { H } \\
\text { 等 } \\
\end{array}$ & קָ & 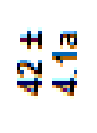 & 茾畕 & 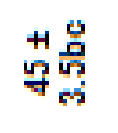 & 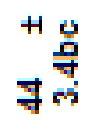 \\
\hline & 월 है & 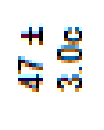 & $\stackrel{+}{m} \underset{m}{\stackrel{m}{+}}$ & H & 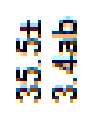 & 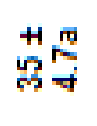 & 䓵塄 & 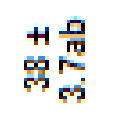 & 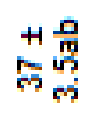 \\
\hline 窇 & 壱/ & 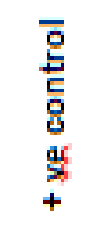 & 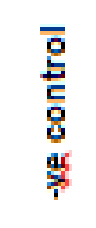 & ํํำ & 亭 & 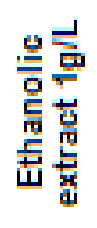 & 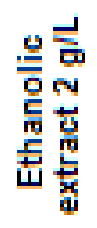 & 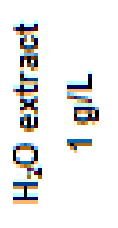 & 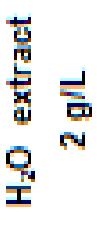 \\
\hline
\end{tabular}


M. A Habib, et al.,

Table (7): Liver function enzymes activity of the experimental animals:

\begin{tabular}{|c|c|c|c|c|c|c|}
\hline \multirow{2}{*}{$\underbrace{\text { Parameter }}_{\text {Treatment }}$} & \multicolumn{3}{|c|}{ ALT (U/L) } & \multicolumn{3}{|c|}{ AST (U/L) } \\
\hline & $\begin{array}{l}\text { Zero } \\
\text { time }\end{array}$ & Day 30 & Day 60 & Zero time & Day 30 & Day 60 \\
\hline + ve control & $48 \pm 4.6^{\mathrm{e}}$ & $43 \pm 4.1^{c d}$ & $40 \pm 4.4^{c}$ & $51 \pm 4.6^{\mathrm{e}}$ & $45 \pm 4.3^{d}$ & $42 \pm 4.1^{c}$ \\
\hline - ve control & $27 \pm 4.4^{\mathrm{a}}$ & $27 \pm 4.1^{\mathrm{a}}$ & $26 \pm 3.1^{a}$ & $28 \pm 4.6^{\mathrm{a}}$ & $27 \pm 4.3^{\mathrm{a}}$ & $27 \pm 5.1^{\mathrm{a}}$ \\
\hline $\begin{array}{c}\text { Onion powder } \\
2 \%\end{array}$ & $35 \pm 5.1^{\mathrm{ab}}$ & $38 \pm 5.1^{b c}$ & $41 \pm 4.1^{c}$ & $38 \pm 4.7^{\mathrm{ab}}$ & $39 \pm 5.3^{b c}$ & $44 \pm 4.1^{c}$ \\
\hline $\begin{array}{c}\text { Onion powder } \\
4 \%\end{array}$ & $34 \pm 4.4^{b}$ & $37 \pm 4.4^{\mathrm{bc}}$ & $41 \pm 4.3^{c}$ & $37 \pm 4.8^{\mathrm{a}}$ & $38 \pm 4.7^{b c}$ & $46 \pm 4.2^{c}$ \\
\hline $\begin{array}{c}\text { Ethanolic } \\
\text { extract } 1 \mathrm{~g} / \mathrm{L}\end{array}$ & $32 \pm 3.8^{\mathrm{a}}$ & $36 \pm 4.3^{b c}$ & $40 \pm 4.4^{c}$ & $36 \pm 5.1^{\mathrm{a}}$ & $38 \pm 4.3^{b c}$ & $45 \pm 5.1^{\text {ce }}$ \\
\hline $\begin{array}{c}\text { Ethanolic } \\
\text { extract } 2 \mathrm{~g} / \mathrm{L}\end{array}$ & $30.5 \pm 4^{a}$ & $35 \pm 4.4^{\mathrm{ab}}$ & $40 \pm 4.6^{c}$ & $34 \pm 4.4^{\mathrm{a}}$ & $39 \pm 5.2^{b c}$ & $46 \pm 4.7^{\mathrm{ce}}$ \\
\hline $\begin{array}{c}\mathrm{H} 2 \mathrm{O} \text { extract } \\
1 \mathrm{~g} / \mathrm{L}\end{array}$ & $37 \pm 5.1^{\mathrm{ab}}$ & $37 \pm 4.1^{b c}$ & $38 \pm 5.1^{b}$ & $40 \pm 4.9^{b c}$ & $41 \pm 5.1^{\mathrm{c}}$ & $45 \pm 4.4^{\mathrm{ce}}$ \\
\hline $\begin{array}{c}\mathrm{H} 2 \mathrm{O} \text { extract } \\
2 \mathrm{~g} / \mathrm{L}\end{array}$ & $36 \pm 5.9^{a b}$ & $37 \pm 3.6^{b c}$ & $39 \pm 4.4^{b}$ & $39 \pm 4.7^{\mathrm{ab}}$ & $40 \pm 4.4^{c}$ & $45 \pm 4.1^{\mathrm{ce}}$ \\
\hline
\end{tabular}

Values represent means \pm S.D. obtained from 6 treatments, means in the same column followed by the same letters don't differ significantly, and when the means followed by different letters differ significantly at $(p>0.01)$.

Results also indicate that onion ethanolic extract treatment $2 \mathrm{~g} / \mathrm{L}$ is the best among all treatments followed by onion ethanolic extract treatment $1 \mathrm{~g} / \mathrm{L}$ and both of them showed a significant decrease which was closed to the normal control group. These results are in line with the results published by, Stajner et al; (2006) and Emamat et al; (2016).

\section{Conclusion}

The results of the current study showed that the ethanol and water extracts of onion contain a good amounts of total phenols and total flavonoids.

In summary, treatment of onion was beneficial to control the hyperlipidemia, and improving the levels of some blood parameters such as, total cholesterol, HDL, LDL, TG, ALT, AST, creatinine, urea, uric acid, blood glucose. Those are indicators for lipid profile, liver function, kidneys function and blood sugar of the experimental albino rats.

\section{REFERENCES}

A.O.A.C. (2005). Association of official analytical chemists- official methods of analysis, Washington, DC.

Ashraf, R., K. Aamir and A.R. Shaikh (2005). Effects of garlic on dyslipidemia in patients with type 2 diabetes mellitus. J. Ayub. .Med. Coll. Abbottabad.; 17(3): 60-64.

Atkin, M., D. Laight and M.H. Cummings (2016). The effects of garlic extract upon endothelial function, vascular inflammation, oxidative stress and insulin resistance in adults with type 2 diabetes at high cardiovascular risk. A pilot double blind randomized placebo 
controlled trial. J. Diabetes Complications. ; 30: 723-727.

Dewanto, V., X. Wu, K.K. Adom and R.H. Liu (2002). Thermal processing enhances the nutritional value of tomatoes by increasing total antioxidant activity. Journal of Agricultural and Food Chemistry,50 (10): 3010 - 3014.

Duan, Y., D.H. Jin, H.S. Kim, J.H. Seong, Y.G. Lee, D.S. Kim and S.H. Jang (2015). Analysis of total phenol, flavonoid content and antiox-idant activity of various extraction solvents extracts from onion (Allium cepaL.) peels. J. Korean Oil Chem. Soc. 32: 418-426.

Goupy, P., M. Hugues, Dubois P. and Amiot M.J. (1999). Antioxidant isolated, phenolic compounds. J.. Sci. of Food and A gric., 79: 1625 1634.

Dubois, M., K. A. Gilles, J. K. Hamilton, P. A. Rebers and F. Smith (1956). Colorimetric Method for Determination of Sugars and Related Substances Anal. Chem., 28 (3): 350-356

Emamat, H., F. Foroughi, H. Eini-Zinab, M. Taghizadeh, $M$. Rismanchi and $A$. Hekmatdoost (2016). The effects of onion consumption on treatment of metabolic, histologic, and inflammatory features of nonalcoholic fatty liver disease. J. Diabetes Metab. Disord., 15:1175-1183.

Gauthami, M., N. Srinivasan, M.G. Neelam, K. Boopalan and Thirumurugan K. (2015). Synthesis of Silver Nanoparticles using Cinnamomum zeylanicum Bark Extract and its Antioxidant Activity. Nanosci. Nanotechnol. Asia. 5(1): 2-7.

Haidari, F., M.R. Rashidi, S.A. Keshavarz, S.A. Mahboob, M.R. Eshraghian and M.M. Shahi (2008). Effects of onion on serum uric acid levels and hepatic xanthine dehydrogenase/xanthine oxidase activities in hype ruricemic rats. Pak J. Biol. Sci; 11: 1779-1784.

International Journal of Biochemistry Research \& Review (2014). Sciencedomain international., Hepatoprotective Effects of Crude Extracts of Tomato and Onion in Rats Exposed to Locally Processed Beef.; 4(2): 193-203.

Jelodar Gholamali, A., M. Maleki, M. H. Motadayen and S. Sirus (2005), Effect of fenugreek, onion and garlic on blood glucose and histopathology of pancreas of alloxan-induced diabetic rats, Indian J. Med. Sci., 59: 64-69.

Kendrick, J. S., J. Wilkinson, I. J. Cartwright, S. Lawrence and J. A. Higgins (1998). Regulation of the assembly and secretion of very low density lipoproteins by the liver. Biological Chem. 379: 1033-1040.

Kim, J., Y.J. Cha, K.H. Lee and E. Park (2013). Effect of onion peel extract supplementation on the lipid profile and antioxidative status of healthy young women: a randomized, placebo-controlled, doubleblind, crossover trial. Nut. Res. Practice, 7(5): 373-379.

Kumar, N., VK Singh, P.K. Sharma and R. Dudhe (2011). Immunomodulatory effects of some traditional medicinal plants. J. Chem. Pharm. Res; 3(1): 675-684.

Sainani, B. S., D. B. Desai, N. H. Gorhe, S. M. Natu and P. G. Sanaui (1979). Effect of dietary garlic and onion in experimental atherosclerosis. Jpn Heart J; 20: 351- 35

Skerget, M., L. Majhenic ${ }^{\circ}$ M. Bezjak and $Z^{\circ}$. Knez (2009). Antioxidant, radical scavenging and antimicrobial activities of red onion (Allium cepa L.) skin and edible part extracts. Chem. Biochem. Eng. Q. 23: 435-444. 
M. A Habib, et al.,

Stajner, D., N. Milic, J. CanadanovicBrunet, A. Kapor, M. Stajner and BM. Popovic (2006). Exploring Allium species as a source of potential medicinal agents. Phytother. Res. PTR.; 20: 581-584.

Tejani, A. (2013). Garlic for the prevention of cardiovascular morbidity and mortality in hypertensive patients: summaries of nursing care-related systematic, reviews from the cochrane library. Cochrane Database Syst. Rev. ;11(1):CD 007653.
Upadhyay, R.K. (2016). Nutraceutical, pharmaceutical and therapeutic uses of Allium cepa: A review. Int. journal Green Pharm., 10: 1212-1216.

Wouters, K., R. Shiri-Sverdlov, P.J. Van Gorp, M. Van Bilsen and MH. Hofker (2005). Understanding hyperlipidemia and atherosclerosis: Lessons from genetically modified apoe and Idlr mice. Clin. Chem. Lab. Med.; 43: 470479. 


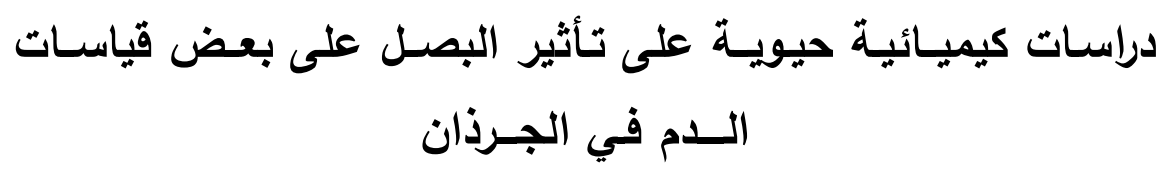

محمد عبد السـلام حبيب، خـالد مــمون طــه، أيمـن فوزى عبـاس شتـا

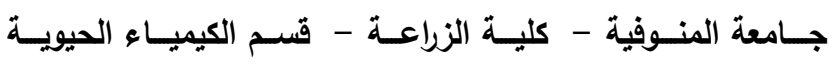

الملخص العربى

يهاف هذا البحث الى دراسة التركيب الكيميائي للبصل وكذلك محتوى البصل من المركبات الفينولية والفلافونويدات .

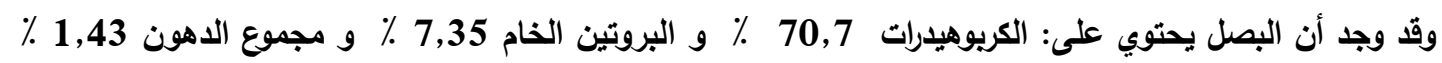

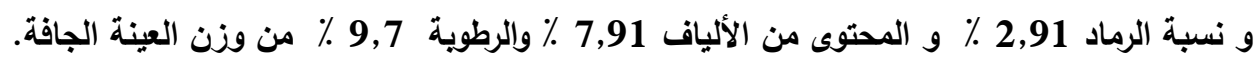

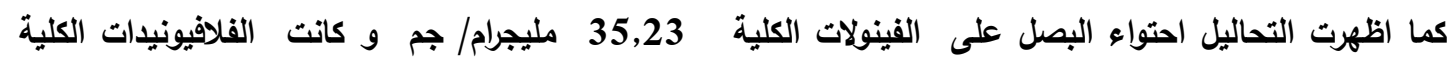
23,81 مليجرام/ جم من وزن النبات.

ويإجراء التحليل الكروماتوجرافى تبين أن البصل يحتوى أيضا على عدد 17 مركب فينولى ، وكانت النسبة العالية

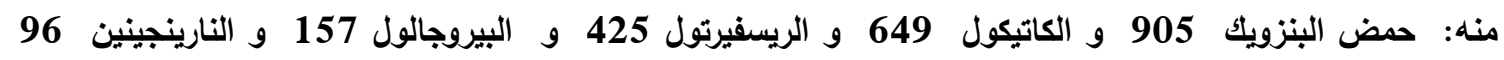

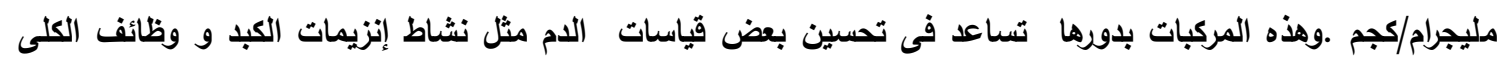
ومستويات الاهون ومستوي الجلوكوز بالام.

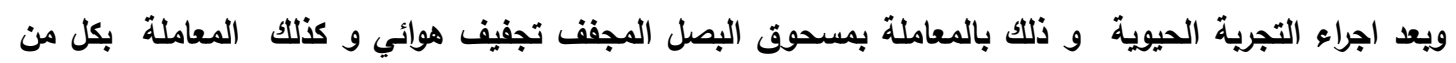

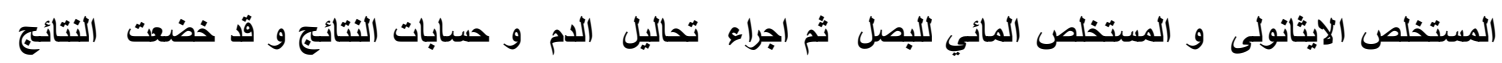

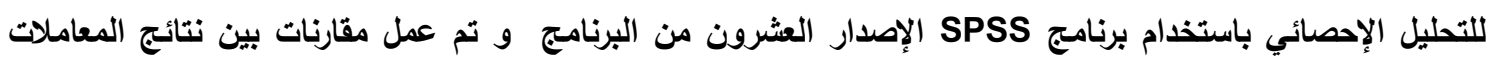
بالمستخلصات المختلفة. وقد تم التوصل الى أفضل المعاملات من خلال مقارنات النتائج.

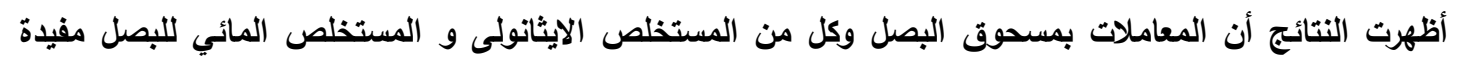

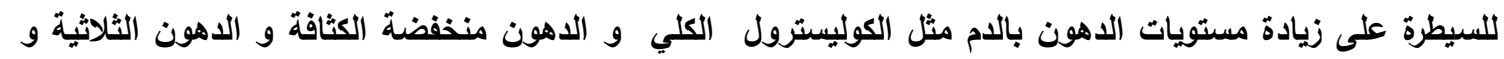
أظهرت تحسن في مستوى الاهون عالية الكثافة وقد حسنت أيضا من نثاط انزيمات الكبد ALT و مستويات بعض معاملات الام الاخرى مثل وظائف الكلى في صورة انخفاض البولينا و الكرياتينين و حمض البوليك وخفضت ايضا نسبة جلوكوز الام. 